Is COVID-19 a Threat to Liberal Democracy?

Kevin Arceneaux ${ }^{\mathrm{a}}$, Bert N. Bakker ${ }^{\mathrm{b}}$, Sara B. Hobolt ${ }^{\mathrm{c}}$, and Catherine E. De Vries ${ }^{\mathrm{d}}$ aDepartment of Political Science, Temple University

${ }^{\mathrm{b}}$ Amsterdam School of Communication Research, University of Amsterdam ${ }^{\mathrm{c}}$ Department of Government, London School of Economics and Political Science ${ }^{\mathrm{d}}$ Department of Social and Political Sciences, Bocconi University 


\begin{abstract}
A defining feature of liberal democracy is the respect for and protection of core civil liberties. Yet, major crises, such as wars, natural disasters and pandemics, can provide a pretext to undermine liberal democratic norms. This raises questions of whether citizens are willing to support policies that violate their civil liberties in a crisis and whether some individuals are more likely to a support such encroachments. We conducted a series well-powered preregistered conjoint and vignette experiments in the US and UK during the first wave of the COVID-19 pandemic. We find that people's attitudes are relatively malleable and that endorsements by an in-group party and trusted experts can shift support for measures that erode civil liberties. However, the evidence also reveals resistance to certain illiberal policy measures, including banning protests and indefinitely postponing elections. This indicates the presence of liberal democratic norms, even when partisan elites promote illiberal policies.
\end{abstract}

Keywords: :iberal democracy | COVID-19 | Public opinion | Conjoint experiments 


\section{Is COVID-19 a Threat to Liberal Democracy?}

Democracy is in retreat across much of the world mechkova2017much. This retreat is not the result of dramatic events, such as coups or foreign invasions from authoritarian regimes. Instead, it has arisen from the democratic process itself, as democratically elected leaders take actions that subvert constitutional limits on their power and gradually erode the foundation of democracy (Levitsky \& Ziblatt, 2018).

The United States, for instance, with its long-established constitutional system of checks and balances, has not been immune from democratic backsliding. Political scientists have observed a marked drop in respect for constitutional limits on executive power in recent year in the US (Carey, Helmke, Nyhan, \& Stokes, 2020).

The COVID-19 pandemic has called for strong executive action to protect public health. Yet, such a crisis can also provide a pretext for leaders who seek to attack core liberal democratic institutions and norms. For example, the Hungarian Prime Minister, Viktor Orban, who has been under criticism for weakening the country's democratic institutions (Kelemen, 2020), has used the crisis to acquire powers to rule by decree (Novak \& Kingsley, 2020). Israel passed a law banning protests during the second coronavirus lockdown ("Anti-democratic law': Israel bans mass protests as Covid lockdown tightens", 2020). In the US, some politicians have suggested the pandemic as a reason for banning protests, postponing elections, and adjourning Congress (Vazquez \& Mattingly, 2020). There is a danger that such sweeping executive powers could lead to a more long-term erosion of key liberal democratic norms in society, such as reduction in civil liberties and media freedom, constraints on parliamentary oversight of the executive, and suppression of public protest and regime criticism (Levitsky \& Ziblatt, 2018; Sedelmeier, 2017). 
In this paper, we seek to understand the extent to which citizens in democracies are willing to accept severe restrictions on the freedoms that underlie liberal democracy in order to manage the threat posed by COVID-19. In our analysis, we separate limitations on individual freedoms to promote public health that are necessary nuisances, but do not fundamentally undermine core liberal democratic norms, from those that do. For instance, requirements to "social distance" or wear face masks do not impede people from engaging in constitutionally protected rights, whereas extrajudicial punishments for failing to social distance, absolute bans on non-violent protests, censoring the press, abrogating popularly-elected institutions, or suppressing the right to vote could erode the foundation of democracy.

Democracy relies on its core norms being shared and defended by the broader society (Dahl, 1989). Nonetheless, extant research offers mixed evidence about the degree to which citizens of liberal democracies hold a principled commitment to civil liberties (Becher \& Brouard, 2020; Chong, 1993; Donovan, 2019; Graham \& Svolik, 2020; Mondak \& Hurwitz, 2012). Moreover, studies have shown that many people are willing to trade civil liberties for a sense of security in response to external threats (Davis \& Silver, 2004; Merolla \& Zechmeister, 2009).

Given the severity of the COVID-19 pandemic, this raises questions of whether such core democratic norms are still protected and will be supported in a time of crisis. To examine this, we conducted a series of well-powered preregistered conjoint experiments (https://osf.io/xn53k/) and vignette experiments (https://osf.io/9s64b/) in the United States (US) and the United Kingdom (UK) in the spring and summer of 2020 that identify the conditions under which people are willing to trade liberal democratic values for a sense of security. The US and UK offer a 
revealing context to study the influence of COVID-19 on people's willingness to give up liberal rights. Both possess an Anglo-Saxon culture that prizes individualism and individualistic notions of liberty. Both countries have long-established constitutional systems of government that are ostensibly committed to liberal democracy. If the public can resist autocratic appeals to trade liberty for security, it should be found in countries like these (for more details on the development of COVID-19 in the spring of 2020 in the US and UK see Appendix A.4).

We studied two interrelated questions. First, we investigated whether there are some rights that are more likely to be traded by the public for a sense of security than others. In particular, we considered the basic elements of civil liberties in modern democracies: freedom of movement, limits on behavior in public, government surveillance, procedural rights, rights to protest, press freedoms, and the right to hold elections. Second, we investigated whether some individuals are more likely to support encroachments on civil liberties to give the state a free hand in fighting the pandemic.

With respect to the question about which rights people are more willing to trade off, we did not have, nor did previous research provide, strong expectations. We find that participants' attitudes toward civil liberties are fairly malleable in both the US and UK, but that there is an overall tendency to resist policy proposals that include clear violations of constitutional rights, such as censoring the press, depriving the accused of due process, banning protests, or indefinitely postponing elections.

With respect to the question about who is more likely to accept the erosion of civil liberties, we find consistent evidence in our conjoint experiments that participants' are more likely to accept illiberal proposals if they are championed by politicians who share the participants' political party — especially in the UK. Yet again proposals that 
undermine core civil liberties fare less well even if they are proposed by a co-partisan especially in the US.

To dig deeper and address the concern that the policy proposals we evaluated were not specific enough, we conducted a set of follow-up vignette experiments where we find that partisan appeals to ban specific protests (we used the Black Lives Matter (BLM) protest as a focal point) and postpone the US presidential election largely fell on deaf ears, even among those who should be predisposed to accept the illiberal message (e.g., anti-BLM participants who identify with the party affiliation of the messenger or Republicans who read a proposal from President Trump to consider postponing the election). While these findings corroborate both the importance of partisan identification in shaping people's attitudes about policies - in case of the conjoint experiments (Campbell, Converse, Miller, \& Stokes, 1960; Cohen, 2003; Huddy, Mason, \& Aarøe, 2015; Westwood et al., 2018), they also illustrate its limitations - in case of the vignette experiments (Arceneaux \& Vander Wielen, 2017; Bakker, Lelkes, \& Malka, 2020; Orr \& Huber, 2020).

In addition to partisanship, we also investigated the influence of personality traits and other individual differences that previous research suggests should structure people's acceptance of illiberal policies in order to combat the COVID-19 pandemic: authoritarianism (Altemeyer, 1996; Feldman, 2003; Hetherington \& Suhay, 2011; Stenner, 2005), pathogen disgust sensitivity (Aarøe, Petersen, \& Arceneaux, 2017; Kam \& Estes, 2016; Tybur et al., 2016) and anxiety (Brouard, Vasilopoulos, \& Becher, 2018; Harper, Satchell, Fido, \& Latzman, 2020; Merolla \& Zechmeister, 2009). Intriguingly, contrary to our preregistered expectations, we find no consistent evidence in these well-powered tests that these individual-level traits cause people to be more or less 
supportive of assaults on civil liberties in the name of fighting the pandemic. The same is true for age, contrary to our preregistered expectation those that are more at risk of COVID-19 are not more likely to support illiberal policies.

\section{Overview of experiments}

We partnered with a respected survey firm (YouGov) to collect nationally diverse samples of adults living in the US and UK. In the first round of experiments, fielded in May 19-20, 2020 in the US $(\mathrm{N}=1450)$ and UK $(\mathrm{N}=1750)$, we employed a conjoint experiment (Hainmueller, Hopkins, \& Yamamoto, 2014; Leeper, Hobolt, \& Tilley, 2020) to investigate the relative impact of the various attributes of liberal democracy that people are willing to give up in the fight against the SARS-CoV 2 virus that causes COVID-19. A conjoint experiment is a high-dimensional factorial experiment with the distinct advantage that it allows researchers to uncover the relative influence of different factors in how people make decisions over bundled outcomes (Hainmueller et al., 2014). In a conjoint study, participants are shown a series of vignettes that vary according to a determined set of features, with combinations of features randomly varied (Auspurg \& Hinz, 2014; Hainmueller et al., 2014; Jasso, 2006; Leeper et al., 2020). One critique of conjoint experiments is that they ask respondents to evaluate abstract policies, but in our study we selected policy proposals that had been debated and implemented in various forms across the world. Moreover, the design allows for more truthful answers as it reduces social desirability bias (Horiuchi, Markovich, \& Yamamoto, 2018; Teele, Kalla, \& Rosenbluth, 2018). In our conjoint experiment, respondents were asked to evaluate a successive series of tables containing two hypothetical policy proposals designed to combat COVID-19 (for a stylistic example of a round in the conjoint experiment, see Table 1 below), each consisting of a set of attributes with implications 
for individual, procedural and constitutional rights - see Appendix A.4 for the details of the design. The attributes are randomly varied in each table to form a series of pairwise comparisons. Participants then choose which of the two policies they support (A or B) and evaluate each policy on a scale from not at all supportive (0) to fully supportive (10).

Table 1

Example round of the conjoint experiment

\begin{tabular}{|l|l|}
\hline Policy A & Policy B \\
\hline $\begin{array}{l}\text { This is a proposal by a Democratic Member } \\
\text { of Congress }\end{array}$ & $\begin{array}{l}\text { This is a proposal by a Republican Member of } \\
\text { Congress }\end{array}$ \\
\hline $\begin{array}{l}\text { It is mandatory for individuals to stay at home } \\
\text { (except for food, health reasons, exercise or if } \\
\text { they are essential workers) }\end{array}$ & $\begin{array}{l}\text { Individuals are encouraged to stay at home, } \\
\text { but this is voluntary }\end{array}$ \\
\hline $\begin{array}{l}\text { Individuals are encouraged to use a phone app } \\
\text { that can trace contact, but this is voluntary }\end{array}$ & $\begin{array}{l}\text { Individuals are required to use a phone app } \\
\text { that can trace contact when they are outside } \\
\text { the home }\end{array}$ \\
\hline $\begin{array}{l}\text { Individuals who violate COVID-19 restric- } \\
\text { tions can be fined and detained by the police }\end{array}$ & $\begin{array}{l}\text { Individuals who violate COVID-19 restric- } \\
\text { tions can be given warnings by the police }\end{array}$ \\
\hline $\begin{array}{l}\text { All public protests and gatherings are prohib- } \\
\text { ited }\end{array}$ & $\begin{array}{l}\text { Public protests and gatherings are allowed } \\
\text { given that 6-feet social distancing is adhered } \\
\text { to }\end{array}$ \\
\hline $\begin{array}{l}\text { The news media may air people's views about } \\
\text { COVID-19 even if they conflict with what gov- } \\
\text { ernment officials say is correct }\end{array}$ & $\begin{array}{l}\text { The news media are banned from making } \\
\text { statements about COVID-19 that government } \\
\text { officials say is incorrect }\end{array}$ \\
\hline $\begin{array}{l}\text { Elections should be postponed for a maximum } \\
\text { of } 3 \text { months during the outbreak of the coro- } \\
\text { navirus }\end{array}$ & $\begin{array}{l}\text { All elections should go ahead but only using } \\
\text { vote-by-mail }\end{array}$ \\
\hline
\end{tabular}

After analyzing the conjoint experiment in line with our pre-analysis plan, we partnered again with YouGov to conduct preregistered follow-up surveys in the US (N=3101, fieldwork: July 14-17 2020) and the UK (N=3286, fieldwork: July 13-15 2020) in order to probe the role of partisan cues further through preregistered vignette experiments. These experiments offer a complement to the conjoint experiment because they allow us to further increase the mundane realism of the policy proposals. In the conjoint experiment, for instance, people could imagine banning protests that they liked or didn't like, whereas in the vignette experiment we focused participants' attention on allowing or banning Black Lives Matters related protests. Doing so, provides a strong 
test for whether people's attitudes toward specific groups or politicians (e.g., President Trump) can overpower commitments to protecting civil liberties.

\section{Results from preregistered conjoint experiments in the US and UK}

In Figure 1 we plot the marginal means (Leeper et al., 2020) of the different levels of each of the eight attributes on the support for the policy (see Appendix A for the sample A.7, design A.4 and analysis plan A.8). The marginal mean is simply an estimate of the average support for policy proposals containing a given feature - see for a discussion (Leeper et al., 2020). The left hand column of Figure 1 provides the results from the conjoint experiment in the US, while the right-hand column provides the results for the conjoint experiment in the UK. Each row is an attribute and the marginal means for each level are plotted with confidence intervals that, correct for multiple comparisons as preregistered ( $\mathrm{p}=.0018, \mathrm{z}=3.12)$. We discuss the results country by country and highlight the most important patterns. Note that we did not preregister a priori expectations about which policy would receive more or less support, as such these findings should be considered exploratory.

Starting with individual rights (row 2, left-hand column of Figure 1), we find basically no meaningful difference in support for different policies in the US, while in the UK there is more support for policies that stimulate or force people to stay at home (row 2, right-hand column of Figure 1). The pattern in the UK could very well be a reflection of the support for the government policy at the time of the experiment. In the UK, at the time of the survey, the government guidance was "stay at home" unless you are working in a key sector.

In the US and UK the wearing of masks in shops and public transport receives a little bit more support, while mandatory wearing of masks receives less support (only 
statistically significant in the UK, see (row 3 of Figure 1). The pattern in the UK could reflect the current government policy which was that face covering was encouraged but not mandatory at the time of the experiment.

When it comes to surveillance (row 4, left-hand column of Figure 1), Americans and British respondents support the state encouraging people to submit to contact tracing. There is less support in both countries for essentially having no contract tracing regime (especially in the UK) as well as a mandatory contact tracing requirement (especially in the US).

Participants in the US and UK are both less supportive of illiberal policies where the police can fine and detain people without the right to appeal, while in both countries they are supportive of liberal policies where the policy can warn people to obey to COVID-19 policies. The right to protest is supported in both countries if social distancing is maintained (row 6 of Figure 1). Participants in both the US and UK respect the freedom of the press, as they are more supportive of policies where critical coverage is allowed, while a policy proposing censoring media receives less support (row 7 of Figure 1).

Finally, in the UK the range of election proposals do not really affect policy support, while in the US there is more support for policies where elections continue to take place, while postponing the elections is opposed (row 8 of Figure 1).

To conclude, we see that in both the US and UK illiberal policies receive less support. At the same time people seem to be willing to compromise liberal democratic rights in order to fight the Coronavirus. Interestingly, we also find that it matters greatly who puts forwards the proposal (see first row). Proposals from out-group 
partisans, i.e. a politicians from a party you do not identify with, receive less support. ${ }^{1}$ This suggest heterogeneity in the the treatment effects that we explore below. Using the second dependent variable - self-reported evaluation of the policies - we reach similar conclusions (see Appendix A.11 for the results).

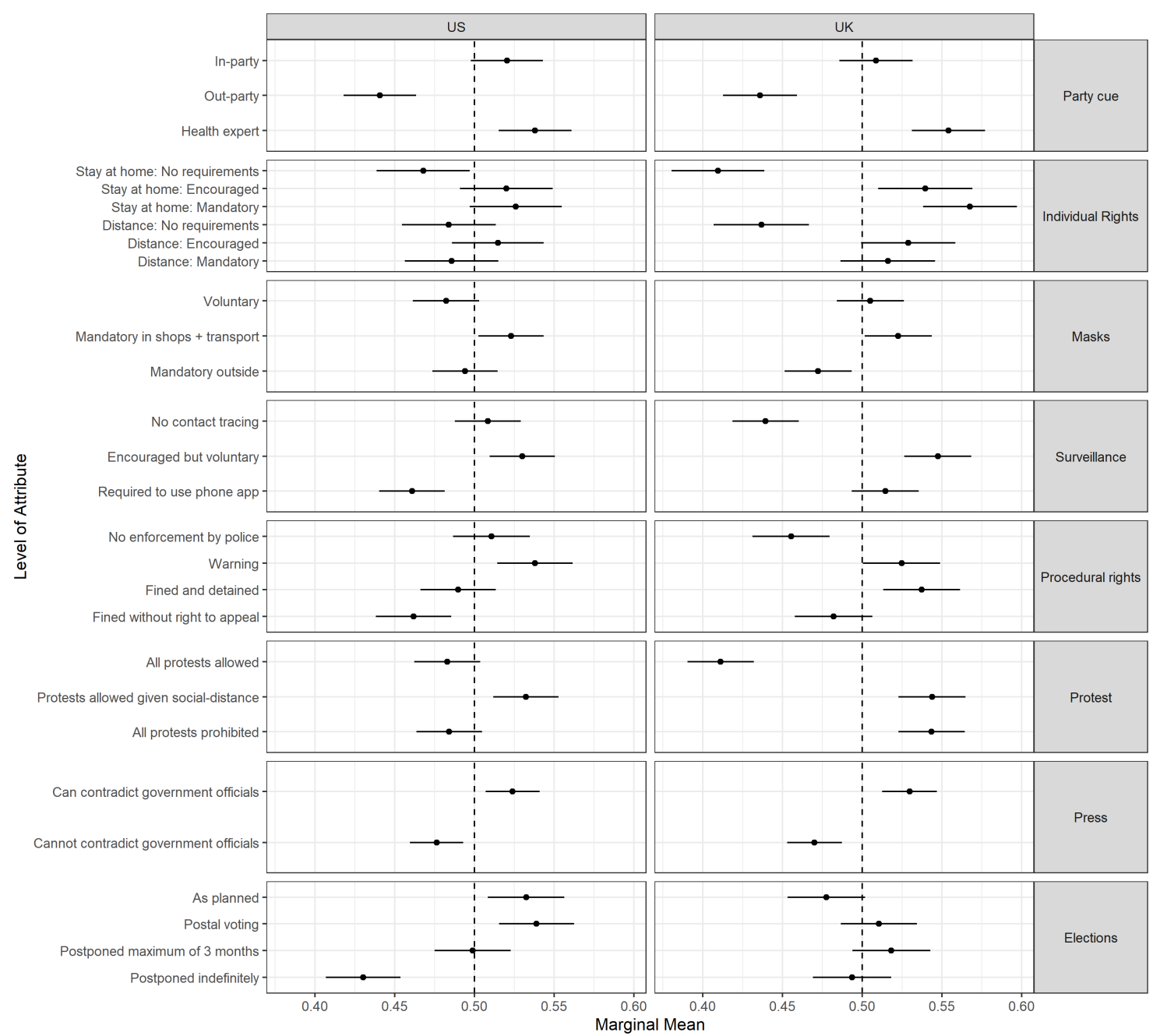

Figure 1. Marginal means of the different levels of each attribute on policy support with confidence intervals that correct for multiple comparisons $(\mathrm{p}=.0018, \mathrm{z}=3.12)$. Results can be derived from the replication files.

\footnotetext{
1 this pattern does not change when we focus upon partisanship instead to in-party and out-party cues (see Appendix A.12).
} 


\section{Preregistered subgroup differences in support for liberal democracy}

Our first preregistered hypothesis was that "we expect that people should be more likely to support restrictions on civil liberties, if endorsed by politicians affiliated with their political party." This receives some empirical support: policies supported by an out-party politician receive less support (top left-hand column of Figure 1), while a policy supported by a health expert receives more support. In-party endorsement does not have a statistically significant effect on policy support. This pattern is strikingly similar in the UK (top right-hand column of Figure 1).

To test this hypothesis more fully, we calculate the marginal means (Leeper et al., 2020) for the following three subgroups (see Figure 2: policies endorsed by the respondent's in-party (blue coefficients), policies endorsed by the respondent's out-party (red-coefficients) and policies endorsed by an health expert (green coefficients). ${ }^{2}$

In line with the preregistered hypothesis, we find that in-party endorsements lead to more support for restrictions on civil liberties. In both countries people are more supportive of mandatory mask wearing (row 2) and the encouragement of contact tracing (row 3). But in-party support does not lead to endorsement of strict restrictions such as mandatory mask wearing outside the home (row 2) or the required use of a phone app for contact tracing (row 3). Likewise, in-party endorsement leads to more support for allowing protests that comply with social distance rules but do not persuade people to ban all protests in the US, while they do in the UK (row 5). In-party support also strengthens the endorsement of policies that support the freedom of the press but do not persuade people to restrict press freedom (row 6). On average in-party support

\footnotetext{
2 this pattern does not change when we focus upon partisanship of the endorser (Republican/Democrat in the US or Conservative/Labour) and the self-reported partisanship of the respondent instead to in-party and out-party cues (see Appendix A.13).
} 
does not affect support for illiberal restrictions of individual rights (row 1) or procedural rights (row 4). The only real instance where the US and UK differ is in the support for elections (row 8). In the US in-party endorsement increases support holding elections on time and expanding the franchise through mail-in voting, while these policies continue to have no effect in the UK.

We did not preregister any expectations about out-party endorsements. But here the pattern is relatively clear. Especially illiberal policies such as mandatory distance rules (row 1), mandatory use of phone apps (row 2), giving fines without due process (row 3), banning protests (row 4), censoring the press (row 5) and postponing elections (row 6) receive even less support once endorsed by a out-party politician.

Finally, the endorsement of health experts increase support for those illiberal policies that are most clearly tied to stemming the rate of infection. The strongest effects individual rights such as mandatory stay at home (row 1), wearing of masks (row 2) and the stimulation to use a contact tracing app (row 3). Yet health experts' endorsement do not increase support of illiberal policies that are core to the operation of democracy, such as the denial of due process (row 4), restrictions of press freedom (row 5) or indefinitely postponing elections.

To conclude, while people's attitudes toward policies to combat COVID-19 are fairly malleable and tend to follow the advice of trusted experts (in-party politicians and public health experts), there appear to be limits on how far people are willing to give up core democratic liberties.

As we noted in the introduction, we also preregistered hypotheses regarding the effects of individual differences. We find no support for these hypotheses in well-powered tests. Authoritarians are not consistently more likely to support illiberal 
policies, neither are those high in pathogen disgust sensitivity, nor those who are afraid of contracting COVID-19. ${ }^{3}$ Using the second dependent variable - self-reported evaluation of the policies - we reach similar conclusions (see Appendix A.11). Tt is important to document these null-findings as null findings are often not published (Franco, Malhotra, \& Simonovits, 2014) which leads to a bias in the literature.

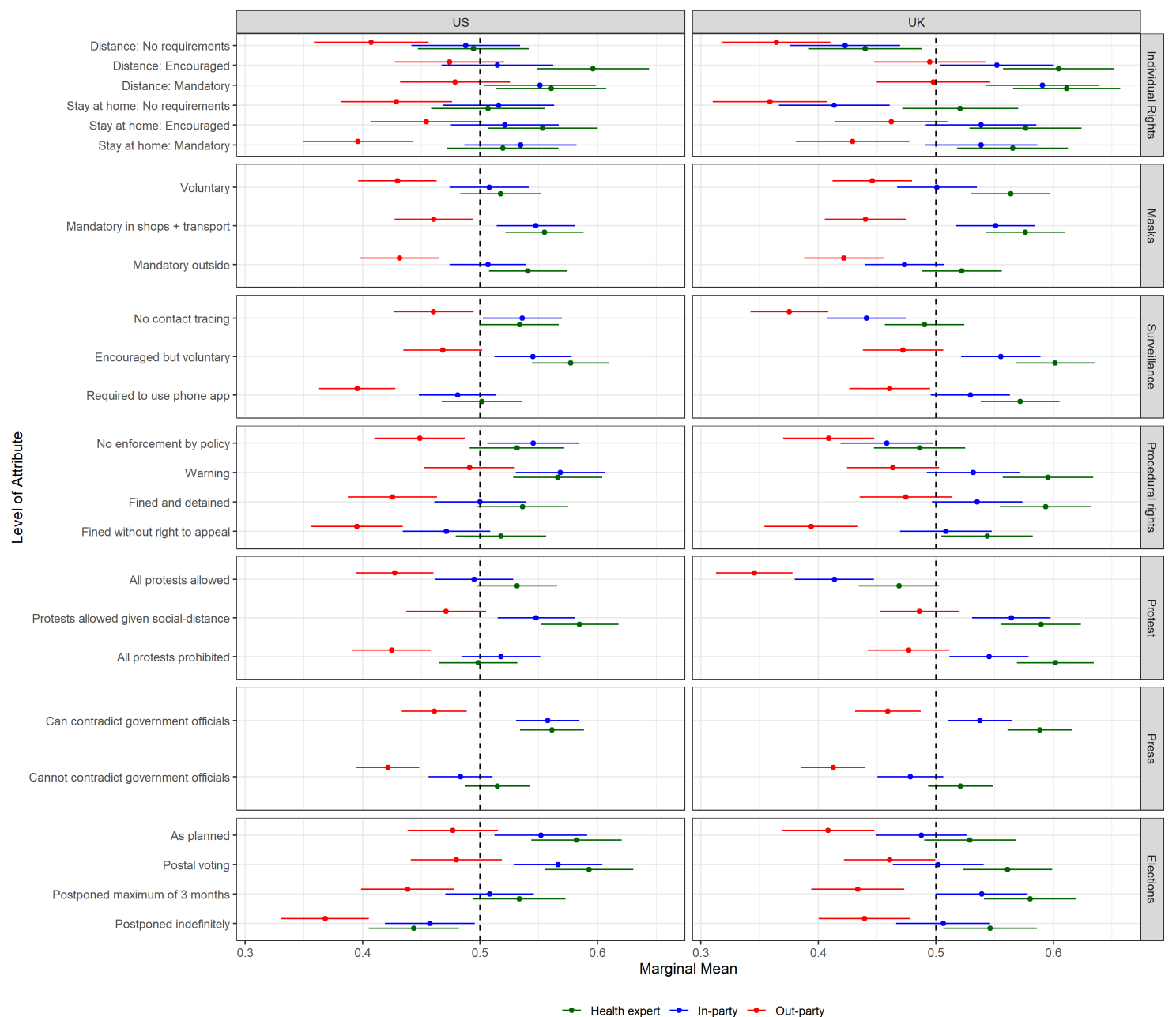

Figure 2. Marginal means of the different levels of each attribute on policy support when a policy is endorsed by the in-party, out-party or a health expert with confidence intervals that correct for multiple comparisons $(\mathrm{p}=.0018, \mathrm{z}=3.12)$. Results can be derived from the replication files.

\footnotetext{
${ }^{3}$ When we use the self-reported policy evaluation, instead of the binary dependent variable, we find that that those who are more fearful of COVID-19., score higher on authoritarianism (see Figure ??) or score higher on disgust sensitivity on average evaluate all COVID policies higher compared to those that score lower on these moderators. This could suggest that these people lower on these traits evaluate policies a bit more more negative compared those those that score positive (see Appendix A.10). We do not find this pattern for age.
} 


\section{Banning Black Life Matters related protests: Preregistered survey-experiments in the US and UK in July 2020}

The conjoint experiment suggests that people in the US and UK place some sharp limits on restricting core civil liberties. Yet public support for policies is often swayed by information regarding group beneficiaries (Nicholson, 2011). Consequently, perhaps participants would support bans on protests if it was a protest that they did not support, or pro-Trump voters would support postponing the presidential election if it was suggested by President Trump. To probe this further, we conducted vignette experiments in the US and UK about banning protests and a vignette experiment in the US about postponing elections.

It is noteworthy that the conjoint experiment took place at the beginning of the Black Lives Matter (BLM) protests in the US and UK. Because these protests were largely popular in the US (Kim Parker \& Anderson, 2020), it is possible that opposition to banning protests in the US conjoint experiment reflected support for BLM. Meanwhile, a majority in the UK did not support BLM protests during the pandemic (Gye, 2020) and this could explain the conjoint results there as well.

Accordingly, the preregistered (see https://osf.io/9s64b/) protests vignette experiment, consistent with the conjoint experiment, randomly varied whether a health expert, in-party, or out-party politician advocated banning protests to stem the spread of COVID-19. It also varied the target of the protest ban: Either pro-BLM protests or "right-wing" anti-BLM protests. Doing so, allows us to see whether people's support for or opposition to BLM (which we measured on the pretest instrument) affects their support for the right to protest (see Appendix B-C for the sample [B.4], design [B.5-6] and analysis plan [C.1]). 
We find that the source of the message and the target of the message has practically no effect on support for banning protests because of COVID-19 in both the US and UK. As can be seen in Figure 3, the mean support for the two policies (dependent variables) do not differ much from each other and the confidence intervals - adjusted for multiple comparisons - overlap which suggests that the treatments do not affect policy support. Also a more formal test of the differences between the means - see Appendix C.2 - does not suggest that treatments had an effect on policy support in both the US and UK.

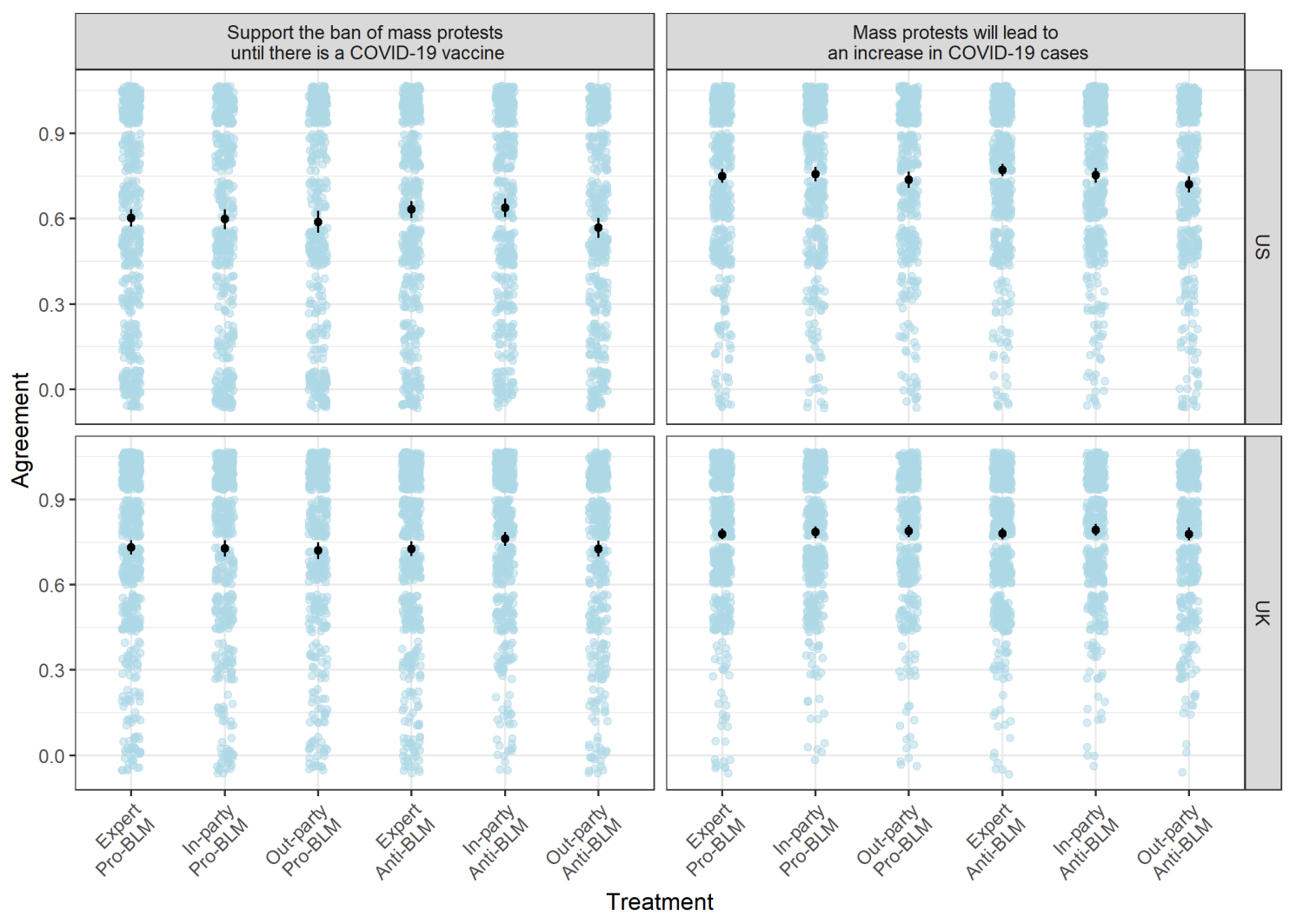

Figure 3. Means and confidence intervals of agreement with the two dependent variables across different treatment conditions in the US (top-row) and UK (bottom-row). The distribution of the observations is plotted in figure. Confidence intervals are correct for multiple comparisons as preregistered $(\mathrm{p}=.0018, \mathrm{z}=3.12$ ). Results can be derived from the replication files.

We also preregistered to test whether the effects of the treatments were moderated by BLM-support or prejudice. But contrary to our preregistered expectations, we find no evidence for these expectations (see Appendix C.3). 


\section{Postponing the elections: Preregistered US experiment in July 2020}

With respect to postponing elections, we focused the vignette experiment on the US, since the election policies appeared to have no effects in the UK and also because the US had a presidential election scheduled for November 2020. The US has never postponed a presidential election, even during times of war, yet the idea was floated by a prominent staff member of the Trump administration in May 2020 (Karni \& Haberman, 2020). The election vignette began by noting the threat of a second wave of the Coronavirus in the fall and then randomly varied whether "some people" (control) "health experts" (trusted source cue), or "the Trump Administration" (partisan source cue) advocated "ruling out" or "not ruling out" that the government postpone "the presidential election until it is safe to vote in person." For more details about the sample, design and analysis strategy see Appendix B.

Following our preregistered analysis plan (see https://osf.io/9s64b/), we analyzed the effects of these experimental manipulations by participants' partisan identities, so for Republicans ( $\mathrm{N}=1018,32.82 \%$ of the sample) and Democrats $(\mathrm{N}=1524$, $49.15 \%$ of the sample) separately, while self-identified independents ( $\mathrm{N}=555$ or $21.80 \%$ of the sample) were excluded from the analyses in line with our pre-analysis plan. In Figure 4, we plot the support for postponing the elections with confidence intervals adjusted for multiple comparisons.

Support for indefinitely postponing the election was restively low $(\mathrm{M}=.29, \mathrm{SD}=.37)$ where 0 is strong opposition to postponing the elections and 1 is strong support for postponing the elections. While we did not preregister to compare mean level of support between Democrats and Republicans, we find that among Democrats, support for postponing elections indefinitely was lower $(\mathrm{M}=.25, \mathrm{SD}=.35)$ compared to 
Republicans $(\mathrm{M}=.36, \mathrm{SD}=.39)$, and this difference is statistically significant $(\mathrm{t}(2536)=-7.278, \mathrm{p}<.001)$.

Turning to our experimental effects, we find little evidence for our preregistered expectation that source cues influenced people's opinions — for or against — about postponing the presidential election. This pattern is similar for self-identified Republicans and self-identified Democrats as can be seen by the means that are very similar across conditions and the overlapping confidence intervals. A more formal test of the treatment effects confirms these patterns (see Appendix D.1). Consequently, we also reject our preregistered expectation that Republicans would be more likely than Democrats to support postponing the presidential election if the Trump Administration advocating considering doing so (see analysis strategy in Appendix D.3). Our exploratory analysis for Democrats also suggest that support for postponing elections is not so flexible. ${ }^{4}$

Following our pre-analysis plan, we also explored whether Republicans and Democrats beliefs about the election outcome shape their reaction to these messages. All things being equal, we preregistered to test whether Republicans who believe the Joe Biden is more likely to win should be more likely to support postponing the election, and Democrats who believe that Donald Trump is more likely to win should be more likely to support postponing the election. Among self-identified Republicans, most believed that President Trump would win the election $(\mathrm{N}=792)$, some believed that both candidates had equal chances $(\mathrm{N}=136)$, and some believed that Biden would win the election $(\mathrm{N}=90)$. We find that self-identified Republicans were more supportive postponing the elections if they believed that both candidates had equal chances of

\footnotetext{
${ }^{4}$ As an exploratory test, we show in Appendix D.2, that the results for self-identified Independents are also not affected by the treatments.
} 
winning the elections $(\mathrm{b}=.127, \mathrm{se}=.036)$ compared to Republicans who believed that Trump would win the elections (see Appendix D.3 for details). Yet, Republicans who believed that Biden would win the elections, were not more supportive of postponing the elections compared to Republicans who believed Trump would win the elections $(b=-.007, \mathrm{se}=.036)$. Among self-identified Democrats, we see that those who believe that both candidates had an equal chance of winning the elections $(b=-.081, \mathrm{se}=.033)$ or that Biden would win the elections $(b=-.199, \mathrm{se}=.027)$ were less supportive of postponing the elections compared to those Democrats who believed that Trump would win the elections. Nonetheless, participants' expectations about which candidate would win the election did not influence the effect of the source cue treatments, which had no effect on support for postponing the election (see Appendix D.3 for details).

\section{Discussion}

Taken together, these studies paint a nuanced portrait of how citizens in two of the world's oldest and most established liberal democracies approach entreaties to trade civil liberties for public health. One the one hand, we do find plenty of evidence that people have fairly flexible attitudes toward proposals to limit individual freedoms in the combat against COVID-19. Consistent with decades of research on the influence of source cues in politics, if a trusted source, such as a public health expert or co-partisan politician, advocate it, people are more likely to support it. On the other hand, there are clear limits to the influence of source cues. Across our four experiments, we find consistent evidence that there is little appetite for undermining rights that are central to liberal democracy. Even in the US, where Republicans were more supportive of postponing the presidential election than Democrats, only a minority of Republicans agreed with the proposal (even if the proposal was floated by the Trump 


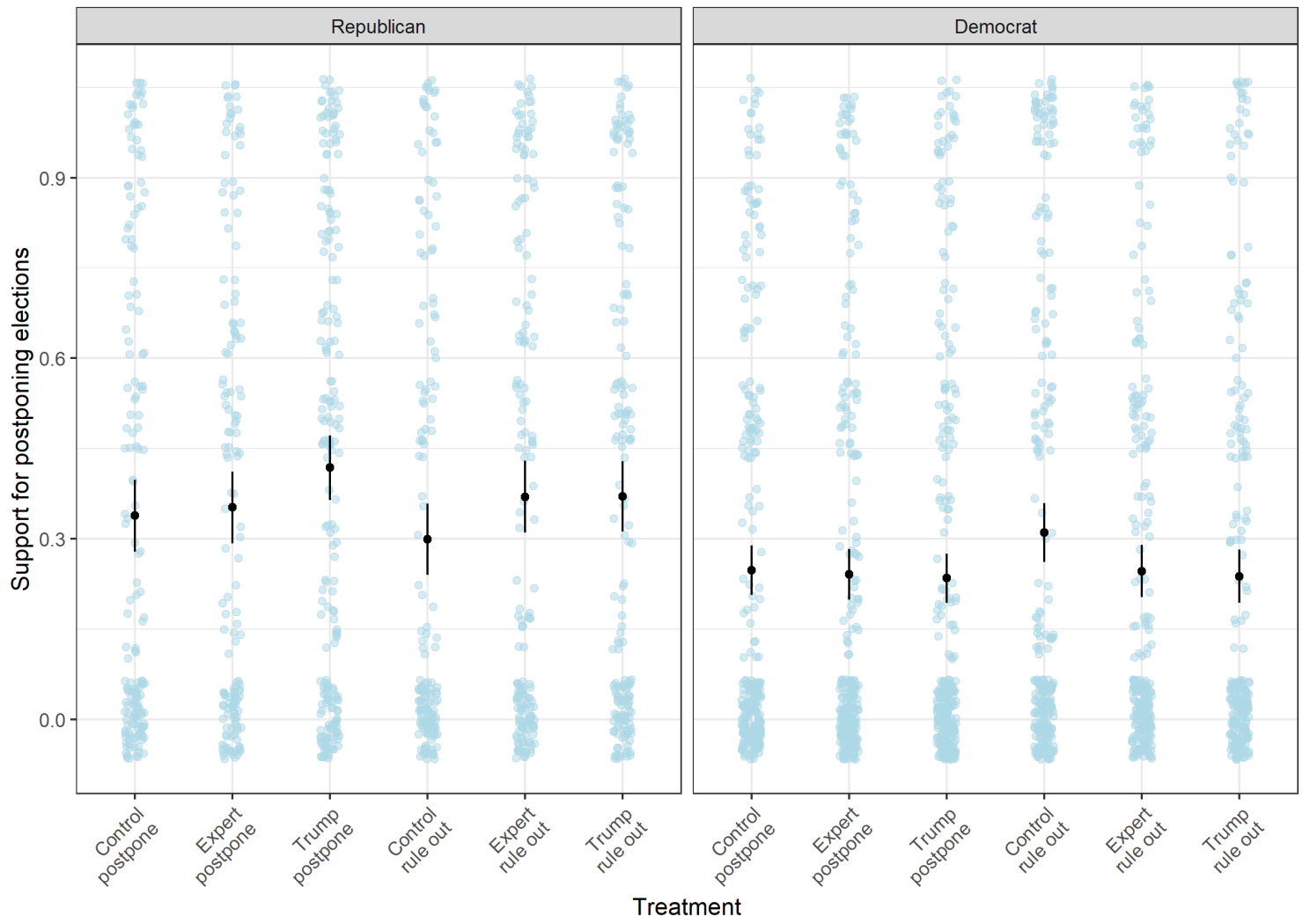

Figure 4. Means and confidence intervals of support for postponing the elections indefinitely across different treatment conditions for self-identified Republicans (left-hand panel) and self-identified Democrats (right-hand panel) in the US in July 2020. The distribution of the observations is plotted in figure. Confidence intervals are correct for multiple comparisons as preregistered $(\mathrm{p}=.0018, \mathrm{z}=3.12)$.

Administration). This suggest that attitudes towards some core liberal democratic principles are less malleable, even in times of acute crisis.

Do these findings imply that liberal democracy is safe? We think not. Liberal democracy is not just premised on public support. It is also premised on support from the major stakeholders in the political system. If a major faction (or set of factions) within the government do not respect the rule of law, public support for liberal democratic norms may not be enough to prevent political elites from undermining the system of government. Nonetheless, these findings do suggest that, at least in the US and UK in the spring and summer of 2020, most citizens will not welcome willingly illiberal policies. As such we are relatively optimistic about the resilience of liberal 
democracy.

\section{Methods}

The Supplementary Information (SI) Appendix consists of four sections. SI Appendix, section A describes the conjoint experiments. In particular the ethical information (A.1), preregistration and deviations from preregistration (A.2-3), the design (A.4), procedures (A.5), measures (A.6), sampling plan (A.7), analysis plan (A.8), outcome neutral quality checks (A.9), preregistered sub-group differences (A.10), results using the self-reported policy evaluation as dependent variables (A.11) and preregistered (A.12) and exploratory robustness checks (A.13).

SI Appendix, section B describes the design of the protests and postpone elections vignette experiments. In particular the ethical information (B.1), preregistration and deviations from preregistration (B.2-3), sampling plan (B.4), procedure (B.5), pre-treatment measures (B.6), the protests vignettes (B.7) and post-treatment measures (B.8) as well as the election vignettes (B.9).

SI Appendix, section $\mathrm{C}$ describes the results and robustness checks of the protests experiments. In particular the hypotheses (C.1), main effects of the treatments (C.2) and moderation effects by BLM-support and prejudcie (C.3). Finally, SI Appendix, section $\mathrm{D}$ describes the results and robustness checks of the election experiment and in particular the treatment effects (D.1), treatment effects among independents (D.2) and moderation by expectations about the outcome of the elections (D.3). 


\section{References}

Aarøe, L., Petersen, M. B., \& Arceneaux, K. (2017). The behavioral immune system shapes political intuitions: Why and how individual differences in disgust sensitivity underlie opposition to immigration. The American Political Science Review, 111(2), 277.

Altemeyer, R. A. (1996). The authoritarian specter. Cambridge, MA: Harvard University Press.

'anti-democratic law': Israel bans mass protests as covid lockdown tightens. (2020, September 30). The Guardian. Retrieved from https://www.theguardian.com/ world/2020/sep/30/anti-democratic-law-israel-bans-mass-protest -lockdown-tightens-netanyahu?CMP=Share_iOSApp_Other

Arceneaux, K., \& Vander Wielen, R. J. (2017). Taming intuition: How reflection minimizes partisan reasoning and promotes democratic accountability. Cambridge University Press.

Auspurg, K., \& Hinz, T. (2014). Factorial survey experiments (Vol. 175). Sage Publications.

Bakker, B. N., Lelkes, Y., \& Malka, A. (2020). Understanding partisan cue receptivity: Tests of predictions from the bounded rationality and expressive utility perspectives. The Journal of Politics, 82(3), 000-000.

Becher, M., \& Brouard, S. (2020). Executive Accountability Beyond Outcomes: Experimental Evidence on Public Evaluations of Powerful Prime Ministers. American Journal of Political Science, 1-17.

Brouard, S., Vasilopoulos, P., \& Becher, M. (2018). Sociodemographic and psychological correlates of compliance with the covid-19 public health measures in 
france. Retrieved from https://osf.io/6n43f

Campbell, A., Converse, P. E., Miller, W. E., \& Stokes, D. E. (1960). The american voter. Chicago: University of Chicago Press.

Carey, J. M., Helmke, G., Nyhan, B., \& Stokes, S. C. (2020). Democracy in the covid-19 era: Bright line watch august 2020 expert survey (Tech. Rep.). Bright Line Watch. Retrieved from http://brightlinewatch.org/ bright-line-watch-august-2020-expert-survey/

Chong, D. (1993). How people think, reason, and feel about rights and liberties. American journal of political science, 867-899.

Cohen, G. L. (2003). Party over policy: The dominating impact of group influence on political beliefs. Journal of personality and social psychology, 85(5), 808.

Dahl, R. A. (1989). Democracy and its critics. Yale University Press.

Davis, D. W., \& Silver, B. D. (2004). Civil liberties vs. security: Public opinion in the context of the terrorist attacks on america. American Journal of Political Science, 48(1), 28-46.

Donovan, T. (2019). Authoritarian attitudes and support for radical right populists. Journal of Elections, Public Opinion and Parties, 29(4), 448-464.

Feldman, S. (2003). Enforcing social conformity: A theory of authoritarianism. Political psychology, 24(1), 41-74.

Franco, A., Malhotra, N., \& Simonovits, G. (2014). Publication bias in the social sciences: Unlocking the file drawer. Science, 345(6203), 1502-1505.

Graham, M. H., \& Svolik, M. W. (2020). Democracy in america? partisanship, polarization, and the robustness of support for democracy in the united states. American Political Science Review, 114(2), 392-409. 
Gye, H. (2020, Jul). Most brits support black lives matter but oppose protests during the pandemic, poll shows. Retrieved from https://inews.co.uk/news/politics/black-lives-matter-protests-poll -exclusive-uk-coronavirus-pandemic-444885

Hainmueller, J., Hopkins, D. J., \& Yamamoto, T. (2014). Causal inference in conjoint analysis: Understanding multidimensional choices via stated preference experiments. Political analysis, 22(1), 1-30.

Harper, C., Satchell, L., Fido, D., \& Latzman, R. D. (2020). Functional fear predicts public health compliance in the COVID-19 pandemic. PsyArXiv [working paper]. doi: 10.31234/osf.io/jkfu3

Hetherington, M., \& Suhay, E. (2011). Authoritarianism, threat, and americans' support for the war on terror. American Journal of Political Science, 55(3), $546-560$.

Horiuchi, Y., Markovich, Z. D., \& Yamamoto, T. (2018). Can conjoint analysis mitigate social desirability bias? MIT Political Science Department Research Paper.

Huddy, L., Mason, L., \& Aarøe, L. (2015). Expressive partisanship: Campaign involvement, political emotion, and partisan identity. American Political Science Review, $109(1), 1-17$.

Jasso, G. (2006). Factorial survey methods for studying beliefs and judgments. Sociological Methods $\&$ Research, $34(3), 334-423$.

Kam, C. D., \& Estes, B. A. (2016). Disgust sensitivity and public demand for protection. The Journal of Politics, 78(2), 481-496.

Karni, A., \& Haberman, M. (2020, May). Kushner, law aside, doesn't rule out delaying 2020 election. The New York Times. Retrieved from https://www.nytimes.com/ 
2020/05/12/us/politics/kushner-election-november.html

Kelemen, R. D. (2020). The european union's authoritarian equilibrium. Journal of European Public Policy, $27(3), 481-499$.

Kim Parker, J. M. H., \& Anderson, M. (2020, Aug). Majorities across racial, ethnic groups express support for the black lives matter movement. Retrieved from https://www . pewsocialtrends .org/2020/06/12/ amid-protests-majorities-across-racial-and-ethnic-groups-express -support-for-the-black-lives-matter-movement/

Leeper, T. J., Hobolt, S. B., \& Tilley, J. (2020). Measuring subgroup preferences in conjoint experiments. Political Analysis, 28(2), 207-221.

Levitsky, S., \& Ziblatt, D. (2018). How democracies die. New York: Broadway Books. Merolla, J. L., \& Zechmeister, E. J. (2009). Democracy at risk: How terrorist threats affect the public. Chicago: University of Chicago Press.

Mondak, J. J., \& Hurwitz, J. (2012). Examining the terror exception: Terrorism and commitments to civil liberties. Public Opinion Quarterly, 76(2), 193-213.

Nicholson, S. P. (2011). Dominating cues and the limits of elite influence. The Journal of Politics, $73(4), 1165-1177$.

Novak, B., \& Kingsley, P. (2020). Orban using emergency powers, but often not for the emergency. New York Times, Section A, 7.

Orr, L. V., \& Huber, G. A. (2020). The policy basis of measured partisan animosity in the united states. American Journal of Political Science, 64(3), 569-586.

Sedelmeier, U. (2017). Political safeguards against democratic backsliding in the eu: the limits of material sanctions and the scope of social pressure. Journal of European Public Policy, 24(3), 337-351. 
Stenner, K. (2005). The authoritarian dynamic. Cambridge: Cambridge University Press.

Teele, D. L., Kalla, J., \& Rosenbluth, F. (2018). The ties that double bind: social roles and women's underrepresentation in politics. American Political Science Review, 112(3), 525-541.

Tybur, J. M., Inbar, Y., Aarøe, L., Barclay, P., Barlow, F. K., De Barra, M., .. others (2016). Parasite stress and pathogen avoidance relate to distinct dimensions of political ideology across 30 nations. Proceedings of the National Academy of Sciences, 113(44), 12408-12413.

Vazquez, M., \& Mattingly, P. (2020, April 15). Trump threatens to invoke never-used constitutional authority to adjourn congress and push nominees through. $C N N$. Retrieved from https://www.cnn.com/2020/04/15/politics/ donald-trump-senate-adjourn-constitution/index.html

Westwood, S. J., Iyengar, S., Walgrave, S., Leonisio, R., Miller, L., \& Strijbis, O. (2018). The tie that divides: Cross-national evidence of the primacy of partyism. European Journal of Political Research, 57(2), 333-354. 